\title{
Triglyceride Level Affecting Shared Susceptibility Genetic Variants in Type 2 Diabetes Mellitus
}

\author{
Katalin Sümegi, Belal. Melegh, Anita Maasz*, Peter Kisfali, Judit Bene and Bela Melegh
}

Department of Medical Genetics, and Szentágothai Research Center, University of Pécs, Pécs, Hungary

\begin{abstract}
Type 2 diabetes mellitus represents a significant global health problem contributing to a considerably increased atherosclerotic burden and cardio- and cerebrovascular risk. Type 2 diabetes mellitus has high incidence and prevalence affecting both genders at any time of life worldwide. Presence of diabetes related phenotypes may represent risk for other metabolic diseases, cardio-, and cerebrovascular disorders, as well. The etiology of type 2 diabetes mellitus is complex; several environmental-, and genetic factors have been identified, which can contribute to the pathogenesis of the disease. Nowadays, numerous genetic loci have been shown to associate with type 2 diabetes mellitus and other diabetic traits, and the number of the identified susceptibility variants is expected to still grow due to rapidly developing field of candidate gene -, linkage-, and genome-wide association studies. The identified genetic variants can affect various metabolic pathways like glucose-, and lipid metabolism, signal transduction and can have effects on transcriptional- and translational levels. Among these, lipid alterations especially increased levels of triglycerides have been found to correlate to various disease phenotypes. It is also well known, that genetic variants identified in triglyceride metabolism are often shared as presence of these SNPs can confer risk for various disorders equally representing a susceptibility link between disorders. The scope of the current review is to summarize shared susceptibility variants, which have effect on the circulating lipid levels and represent risk for type 2 diabetes mellitus.
\end{abstract}

Keywords: Type 2 diabetes mellitus; T2DM; Gene; Susceptibility; SNP; Triglyceride; Genetic variants

\section{Introduction}

Type 2 (non-insulin dependent) diabetes mellitus (T2DM [MIM \#125853]) is the most common form of diabetes accounting for approximately $90 \%$ of all diabetic cases in the world. It is one of the fastest growing diseases; its rate has intensively increased over the past two decades affecting more than 150 million people worldwide nowadays. This number is projected to rise to 366 million by the year 2030 as a consequence of an aging population and changes in lifestyle. The estimates of Wild et al. suggest that the major increase is expected in Asia, especially in India in the next 20 years [1-5].

The prevalence of T2DM shows strong ethnic differences and is very wide-ranging. Currently, T2DM is observed to be the most prevalent in India [6]. Besides, high-risk populations are Pima Indians and South Sea Islanders, where half of which suffer from T2DM, which could be explained by the thrifty hypothesis [7-9]. It is currently estimated that about 25.6 million adults over the age of 20 years have T2DM in the United States, which is $11.3 \%$ of all people in this age group; furthermore, nearly one-third of these cases are undiagnosed $[10,11]$. The European and Asian nations belong to the low-risk populations as the prevalence of T2DM is approximately $5 \%$ or less [12]. The differences in prevalence of T2DM among ethnic groups could be explained by the diverse population structure, some feature of the composition of diet, different life-style and socio-economic factors. The incidence of T2DM increases with age, obesity, physical inactivity and unhealthy diet.

Until recently, T2DM was rarely observed in individuals under the age of 50, but nowadays, it is increasingly occurring at earlier ages affecting males and females equally [13]. T2DM has also been reported in children and adolescents worldwide [14].

T2DM is a complex, multifactorial disorder of carbohydrate metabolism, which is characterized by resistance to insulin-mediated glucose uptake, impaired insulin secretion, and increased hepatic glucose production as early phenomena leading to hyperglycemia, hyperlipidemia and pancreatic beta-cell dysfunction. The T2DMrelated phenotypes create large pathophysiological spectrum from moderate to severe form $[15,16]$. The underlying pathophysiological mechanisms of T2DM have not yet been clearly elucidated. There is a growing number of evidence indicating that the dysfunction of the mitochondrial energy production machinery (OXPHOS), and abnormalities of the innate immune pathways could also play crucial role in development of insulin secretion [17-19]. T2DM is recognized as one of the major causes of morbidity and mortality representing serious health burden of the world [2]. The presence of uncontrolled T2DM can contribute to the development of late complications such as hyperglycemia, lethargy, atherosclerosis, coronary artery disease, stroke, Alzheimer disease, blindness, renal insufficiency, etc $[2,17,20$ 25]. The etiology of T2DM is multifactorial. Complex interplay has been identified between environmental factors, like obesity, dyslipoproteinemia, oxidative stress, lifestyle (smoking, lacking of exercises, alcohol intake), family history of diabetes, and genetic alterations, which contribute to numerous biochemical pathways in the background of T2DM. Additionally, the heritability of T2DM is estimated to be $70 \%-80 \%$ [26]. T2DM has monogenic forms like maturity onset diabetes of the young (MODY) and maternally inherited

*Corresponding author: Anita Maász, Department of Medical Genetics, University of Pécs, and Szentágothai Research Center, Pécs, Szigeti 12, H-7624, Hungary, Tel/Fax: (+36) 72 536000; E-mail: anita.maasz@aok.pte.hu

Received May 28, 2013; Accepted June 29, 2013; Published July 04, 2013

Citation: Sümegi K, Melegh B, Maasz A, Kisfali P, Bene J, et al. (2013) Triglyceride Level Affecting Shared Susceptibility Genetic Variants in Type 2 Diabetes Mellitus. J Diabetes Metab S13: 007. doi:10.4172/2155-6156.S13-007

Copyright: @ 2013 Sümegi K, et al. This is an open-access article distributed unde the terms of the Creative Commons Attribution License, which permits unrestricted use, distribution, and reproduction in any medium, provided the original author and source are credited. 
diabetes and deafness (MIDD) [27,28]; however most of the cases are polygenic.

\section{Shared Alleles of Lipid Metabolism}

The identification of susceptibility genes is difficult due to the considerable heterogeneity of T2DM, and most associations have not been confirmed [29]. Approximately 40 susceptibility loci for the disease have been identified in Caucasian and Asian populations so far [30-35]. In order to recognize genetic loci associated with T2DM, linkage-, candidate gene studies, meta-analyses, and whole genome association studies (GWAS) have been widely performed for various populations [36]. Recently, the great technological development enables research groups to increase the number of identified T2DMsusceptible gene loci using GWAS. As a result, genes such as CDKAL1, SLC30A8, HHEX, EXT2, IGF2BP2, CDKN2B, LOC387761, FTO, TCF7L2, and BCL11A have been reported as susceptible genes for T2DM affecting various metabolic pathways like glucose metabolism, signal transduction, transcription-translation regulation, etc [35,37]. However, one of the most extensively studied elements in T2DM genetic research is the association among naturally occurring genetic variants, plasma lipid levels, particularly triglyceride levels and development of T2DM. Changes in the concentration of plasma lipids, triglyceride and cholesterol levels were found to confer independent risk factors for several metabolic traits, cardio- and cerebrovascular disorders. Plasma triglyceride levels are determined by numerous single gene variants, which may affect independently and/or in combination with other genetic- or environmental factors leading to the characteristic pathophysiological manifestations. The search for genetic variations affecting plasma triglyceride concentrations is still ongoing; several loci have been identified so far. Hereafter, we will summarize the most important genetic alterations affecting the lipid metabolism that can influence the susceptibility for T2DM.

\section{Apolipoprotein E (APOE)}

The apolipoprotein $\mathrm{E}$ is a $34 \mathrm{kDa}$ molecule consisting of 299 amino acids. This plasma glycoprotein is responsible for stabilizing and solubilizing lipoproteins, and serves as a ligand facilitator for the clearance of lipoproteins like chylomicron reside and VLDL remnants [38-40]. The APOE gene on chromosome 19q13.2 has three codominant alleles $\varepsilon 2, \varepsilon 3$ and $\varepsilon 4$ and is determined by two SNPs (rs429358: g.112C > T) and rs7412: g.158T $>$ C). The isoforms differ in single amino acid substitutions ApoE2: 112Cys-158Cys; ApoE3: 112Cys-158Arg; ApoE4: 112Arg-158Arg); their relative frequencies in the Caucasian population are $0.08,0.77$, and 0.15 for $\varepsilon 2$, $\varepsilon 3$ and $\varepsilon 4$, respectively [41]. $\varepsilon 2$ allele is proved to have either pro- or anti-atherogenic nature, depending on its interactions with environmental and other genetic factors. Carriers of the $\varepsilon 2$ alleles have lower total and LDL-cholesterol, higher triglyceride and apoE levels, while carriers of the $\varepsilon 4$ allele have lower levels of apoE, increased plasma levels of total-, LDL-, and VLDLcholesterol compared to $\varepsilon 3 / \varepsilon 3$ homozygotes. It has been concluded that $\varepsilon 4$ allele is a significant risk factor for atherosclerosis, CAD, CHD and MS $[42,43]$. In a case-control study on Thai population, APOE $\varepsilon 4$ allele was found to influence lipid profiles. Additionally, a significantly higher prevalence of $\varepsilon 4$ allele was found in T2DM patients group suggesting that $\varepsilon 4$ allele can be associated with elevated risk of T2DM [44]. However, other studies have shown contradictory results which follow: APOE gene polymorphism was not linked to the progression of islet dysfunction in T2DM [45]. No significant difference was detected in APOE genotype frequencies between hypertriglyceridemic and normotriglyceridemic among T2DM patients [46]; no significant effect of the APOE polymorphism was found on cholesterol levels among diabetics [47]. APOE polymorphism was not associated with lipids in men or women [48]. No association was found of APOE polymorphism with either T2DM or lipid variation [49].

\section{Apolipoprotein C3 (APOC3)}

The ApoCIII enzyme is an essential constituent of triglyceriderich circulating particles, such as VLDL and chylomicrons. The protein synthesized by the liver and intestines serves as a marker of triglyceride-rich lipoprotein levels in the plasma. ApoCIII protein inhibits the hydrolysis of these particles catalyzed by lipoprotein lipase and their hepatic uptake mediated by apolipoprotein E. Therefore, the overexpression of the APOCIII gene leads to hypertriglyceridemia [50]. The APOCIII gene is located on chromosome 11q23. Variants in its sequence (rs1333049: g. $455 \mathrm{~T}>\mathrm{C}$ minor allele frequency (MAF) in Europeans (E): 0.492; and MAF in Asians (A): 0.511; g. $482 \mathrm{C}>\mathrm{T}$ ) have been shown to contribute to increase of APOCIII enzyme levels and hereby to hypertriglyceridemia, metabolic syndrome and CAD [5153]. However, the examination of Pollin et al. revealed that carriers of p.19R $>$ X APOCIII variant have lower serum triglyceride-, and LDLcholesterol levels, and higher HDL-cholesterol levels. In addition, presence of this alteration confers decreased risk for atherosclerosis [54]. Dorfmeister et al. investigated g. $-482 \mathrm{C}>\mathrm{T}$ and g. $1100 \mathrm{C}>\mathrm{T}$ in patients with T2DM of European White, Indian Asian and AfroCaribbean origin. Surprisingly, no significant association was found between lipid levels and APOCIII genetic variants in any ethnic group. Besides, only g.1100C $>\mathrm{T}$ variant was shown to be significantly frequent in European White patients with T2DM suggesting that this variant may have risk nature for T2DM but through mechanism other than effects on triglyceride levels [55].

\section{Apolipoprotein A5 (APOA5)}

This plasma protein, which has been identified in VLDL and HDL particles, is a complex regulator of triglyceride metabolism. APOA5 can facilitate the catabolism of chilomicron and VLDL particles. It contributes to the elimination of triglyceride-rich lipoprotein particles by hydrolysation of plasma triglycerides. APOA5 influences the triglyceride metabolism by two possible mechanisms: (1) enhancing intravascular triglyceride hydrolysis by activating the lipoprotein lipase, and/or (2) decreasing the serum concentration of triglycerides through inhibition of hepatic very-low-density lipoprotein-triglyceride production [56-58]. The protein encoding gene, which is the newly identified member of APOAI-APOCIII-APOAIV gene cluster, is located on chromosome 11q23 [59]. The minor alleles of the most frequently occurring variants, rs662799: $-1131 \mathrm{~T}>\mathrm{C}(\mathrm{MAF}(\mathrm{E})$ : 0.017; MAF(A): 0.291), rs2266788: 1259T>C (MAF(E): 0.084; $\operatorname{MAF}(\mathrm{A})$ : 0.326), rs3135506: $56 \mathrm{C}>\mathrm{G}$ (with Ser to $\operatorname{Trp}$ amino acid change, MAF(E): 0.058; $\operatorname{MAF(A):~0),~rs2072560:~476G>A~(MAF(E):~0.067;~}$ MAF(A): 0.250), have been reported to associate with elevated fasting or postprandial circulating triglyceride levels. Some of them were also found to be risk factors for hypertriglyceridemia, metabolic syndrome, cardio- and cerebrovascular diseases like ischemic stroke, CAD [57,58,60-71]. In a cohort of Indian patients, rs662799 C allele was shown to associate significantly with CAD-T2DM phenotype compared with CAD without T2DM [72]. On the basis of the results of a study conducted on T2DM patients with cerebral infarction Li et al. concluded that rs662799 C allele confers independent genetic risk for T2DM with cerebral infarction [73]. Dorfmeister et al. found in a study performed on T2DM patients with different ethnic origins that carriers of rs662799 C and rs3135506 G allele has elevated triglyceride levels in European Whites and Indian Asians, respectively. Besides, haplotypes 
carrying rs662799 C allele showed significantly increased levels of triglyceride in the European Whites only; while, the haplotype defined by rs3135506 $\mathrm{G}$ allele showed significant triglyceride-raising effect in both Indian Asians and European Whites. In addition, no association was found between the two APOA5 variants and T2DM [55].

\section{Lipoprotein lipase (LPL)}

LPL catalyzes the hydrolysis of triglyceride-rich chilomicrons and VLDL particles; besides it functions as a ligand for receptor-mediated lipoprotein uptake, APOCIII serves as a cofactor for LPL enzyme activity. LPL is synthesized by variety tissues, including skeletal muscle, heart, lung, brain, adipocytes, macrophages and smooth muscle cells [74,75]. Approximately 100 polymorphisms have been described in the LPL gene located on chromosome 8p22. Presence of these variants can lead to loss of function of the mature LPL protein or can modify the LPL enzyme activity. Therefore, these variants can alter plasma lipid levels and can confer risk for several diseases [76,77]. A number of studies have reported an association of p.291N $>S$ and $r$ s1801177: p.9D $>\mathrm{N}$ variants with increased triglyceride- and decreased HDLcholesterol levels [78]. Carriers of these variants have been shown to have an increased risk of insulin resistance and metabolic syndrome [79]. The meta-analysis of $\mathrm{Hu}$ et al. indicates that the $\mathrm{p} .291 \mathrm{~N}>\mathrm{S}$ variant predisposes to CHD and T2DM and severe dyslipidemia, characterized by hypertriglyceridemia and low HDL-cholesterol levels [80]. Besides, rs328: p.447S $>\mathrm{X}$ (MAF(E): 0.125; $\mathrm{MAF}(\mathrm{A})$ : 0.144) variant, which results in the formation of a premature stop codon, has been associated with reduced triglyceride- and increased HDL-cholesterol levels [81]. In Mexican families, this polymorphism can confer susceptibility for the development of hypertension and T2DM [82]. The LPL promoter $-93 \mathrm{~T}>\mathrm{G}$ variant and $\mathrm{p} .9 \mathrm{D}>\mathrm{N}$ polymorphism have been found to be in strong linkage disequilibrium. It has been demonstrated that cooccurrence of $-93 \mathrm{G}$ and p.9D alleles has a triglyceride-lowering effect compared to non-carriers with TT/DD genotype $[83,84]$. In addition, p.312Lys $>$ insC, p.361Thr $>$ insA, and p.312Lys $>$ insC + p.291N $>S$ alterations was found to contribute to hypertriglyceridemia observed in members of type 2 diabetic pedigrees [85]. Other alteration, rs343: g.13836C $>\mathrm{A}(\mathrm{MAF}(\mathrm{E})$ : 0.08; $\mathrm{MAF}(\mathrm{A})$ : 0.169) was observed in association with T2DM and marginally with T2DM-related phenotypes like total- and HDL-cholesterol levels in Korean population [86].

\section{Adipose triglyceride lipase (ATGL)}

ATGL plays a crucial role in the turnover of fatty acids in adipose tissue and liver. It catalyzes the first step in the hydrolysis of triglycerides $[87,88]$. The gene encoding adipose triglyceride lipase is located on chromosome 11p15.5. In an Italian study, four selected variants within ATGL gene (rs7925131: $\mathrm{MAF}(\mathrm{E}): 0.258 ; \operatorname{MAF}(\mathrm{A}): 0.283$; rs7942159: MAF(E): 0.415; MAF(A): 0.613; rs66460720, rs1138693: p.481P $>$ L $\operatorname{MAF}(\mathrm{E}): 0.225 ; \operatorname{MAF}(\mathrm{A}): 0.283$ ) have been examined in familial combined hyperlipidemia, which revealed no association between individual SNPs and the presence of hyperlipidemia; however, two haplotypes were related to lower triglyceride and higher HDLcholesterol levels as well as lower risk of hyperlipidemia [89]. ATGL protein in adipose tissue is decreased with insulin resistance and obesity [90]. Xu et al. found that plasma ATGL levels are significantly increased in patients with T2DM and hypertension compared with those with T2DM [91]. Schoenborn and colleagues investigated the 12 selected genetic variants and haplotypes within the ATGL gene in individuals with obesity, CAD. Significant associations were observed between fasting free fatty acid concentrations, triglyceride levels and several SNPs as well as haplotypes of the gene. Furthermore, rs10902224: 226L $>\mathrm{L}$ and rs11554663: 389L $>\mathrm{L}$ variants and their haplotype showed associations with increased fasting glucose concentrations and risk of T2DM [92].

\section{Plasma phospholipid transfer proteins}

The plasma phospholipid transfer proteins promote the replace of neutral lipids and phospholipids between the lipoproteins. At least two forms of lipid transfer proteins are familiar: cholesteryl ester transfer protein (CETP), which transfers cholesteryl esters (CE) from CE rich particles like HDL and LDL to TG rich particles (VLDL) in exchange of TG. The other protein is phospholipid transfer protein (PLTP), which promotes the transfer of phospholipids from TG rich lipoproteins into HDL. Due to these functions CETP and PLTP have been shown to regulate HDL-, LDL- and VLDL levels of the plasma [93]. The genes encoding CETP and PLTP are located on chromosome 16q21 and 20q13, respectively. Rare or common genetic variants in these genes have been found, which can alter the levels and activity of CETP and PLTP molecules resulting in modification in plasma lipoprotein levels [94]. Variants in PLTP gene have been associated with higher HDL cholesterol levels, while deficiencies in CETP activity have been found to cause dramatic elevation of HDL cholesterol and APOAI levels, as well. Several naturally occurring variants in CETP gene have been shown to be related to the activity of the protein and hereby to the plasma lipid concentrations [95]. The most broadly studied PM in CETP gene is rs708272: g.277C $>\mathrm{T}$ (TaqIB) (MAF(E): 0.5; MAF(A): 0.425 , which has been associated with decreased CETP mass and increased HDL-cholesterol levels, however the results are inconsistent [49,96-98]. CETP variant has been shown to not associate with T2DM in north Indian population, however this polymorphism may be associated with certain complications along with T2DM [49]. Besides, high levels of PLTP and CETP have been found in the plasma of obese patients. PLTP activity and mass have been reported to be abnormally elevated in T2DM and insulin-resistant states $[99,100]$.

\section{Potassium voltage-gated channel (KCNQ1)}

This gene is located on chromosome 11 p15.5 encoding a voltagegated potassium channel, which is required for the repolarization phase of the cardiac action potential and plays a key role in water and salt transport in epithelial cells [101]. Several SNPs have been identified in the KCNQ1 gene. Two of these (rs2237892: $\mathrm{C}>\mathrm{T}$ and rs2237895: $\mathrm{A}>\mathrm{C}$ being in linkage disequilibrium; $\operatorname{MAF}(\mathrm{E}): 0.075 ; \operatorname{MAF}(\mathrm{A}): 0.372$ for $r$ 2237892; $\operatorname{MAF}(\mathrm{E})$ : $0.358 ; \operatorname{MAF}(\mathrm{A}): 0.300$ for $\mathrm{rs} 2237895)$ were found to be associated with T2DM in Asians [102]. Simultaneously, in another GWA study, Unoki et al. detected consistent association of SNPs in KCNQ1 region (rs2283228: C>T MAF(E): 0.076; MAF(A): 0.39 ; rs2237895: A>C; rs2237897: C>T MAF(E): 0.051; $\operatorname{MAF}(\mathrm{A})$ : 0.458 ) with T2DM in independent case-control studies in Singaporean and Danish populations [103]. Since then, this correlation has also been confirmed [104-106]. Data of a meta-analysis, which involved more than 150000 participants from a total of 25 articles, suggest that the rs2237892 and rs2237895 polymorphisms in KCNQ1 are associated with elevated T2DM susceptibility [107]. Potential mechanism of action has also been hypothesized; however, the exact mechanism has not yet been elucidated [104-106]. Additionally, Chen and coworkers described a strong association between CC genotype of rs2283228 and TT genotype in rs2237892 and increased levels of TG in a middle-aged Chinese population. Besides, lower levels of HDL-C and apoA1 were found in patients with CC genotype of rs2283228 [108]. These results provide new evidence that these variants in KCNQ1 gene have an effect on development of T2DM through lipid metabolism. 


\section{Glucokinase regulatory protein (GCKR)}

This regulatory protein inhibits glucokinase in an allosteric manner by forming an inactive heterodimer. Hereby, it stabilizes and protects glucokinase from degradation [109-111]. GCKR is present in pancreatic islets and in the liver. The GCKR gene is located on chromosome 2 p23 containing 19 exons [112,113]. Recently, genomewide association studies identified naturally occurring variants in the GCKR gene [31,113-117]. The most widely studied PMs are the intronic rs780094 (MAF(E): 0.394; $\mathrm{MAF}(\mathrm{A})$ : 0.599) and rs1260326: p.446Leu>Pro $(\mathrm{MAF}(\mathrm{E})$ : 0.420; $\operatorname{MAF}(\mathrm{A})$ : 0.593) variants, which affect the splicing site of the gene. Otherwise, these two variants are in strong linkage disequilibrium. It has been demonstrated in different ethnic groups that these variants reduce fasting plasma glucose concentration and insulin levels and improve insulin resistance, while inversely increase fasting and postprandial serum triglycerides through elevated glucokinase activity [31,115-124]. However, Jaromi et al. could not detect any association between rs 1260326 variant and lipid levels in a stratified Hungarian stroke population [125]. Both functional GCKR variants were widely investigated as candidate susceptibility SNPs for several diseases like coronary artery disease, cardiovascular disease, and T2DM $[31,116,126]$. The results suggest that rs780094 variant does not contribute to CVD and CAD; however, both genetic variants have protective nature against T2DM as people carrying rs1260326 446Leu or rs780094: T allelic variants have decreased risk for T2DM $[31,115,118,123,127,128]$. Results of a Japanese meta-analysis propose that GCKR rs780094 is a common variant for T2DM susceptibility in various ethnic groups [123].

\section{Thrombospondin receptor $(\mathrm{CD} 36)$}

CD36, a transmembrane protein on cell surface, was found to be an important regulator of lipid metabolism promoting endocytosis of oxidized LDL among others. Deficiencies in CD36 activity were found to elevate total cholesterol and triglyceride levels in diabetic CD36 deficient patients $[129,130]$. Besides, decreased activity of CD36 has been linked to several diseases like hypertension, hyperlipidemia, insulin resistance, metabolic syndrome, atherosclerosis and T2DM in Caucasian and African-American populations, as well [130-133]. Many sequence variations have been described in the CD36 gene on chromosome $7 \mathrm{q} 11.2$, which could be responsible for the protein deficiencies. The identified rs1761667: G>A (MAF(A): 0.667) has been shown to be associated with T2DM in the north Indian population [134]. An upstream promoter region alteration (rs1527479: $\mathrm{C}>\mathrm{T}$; $\operatorname{MAF}(\mathrm{E}): 0.566 ; \operatorname{MAF}(\mathrm{A}): 0.221$ ) was shown to have direct association with T2DM and insulin resistance, therefore it may contribute to the etiology of diabetes [135]. However, the results relative to g.478C $>\mathrm{T}$ (p.90Pro $>$ Ser) alteration are inconsistent between Caucasian and Japanese populations.

\section{ATP-binding cassette transporter 1 (ABCA1)}

This protein is the member of ATP-binding cassette (ABC) transporter superfamily, which exports cholesterol, phospholipids, and other lipophilic molecules across extra- and intracellular membranes hereby contributing to pancreatic B-cell cholesterol content. To activate the transport mechanisms, ABCA1 forms lipid domains on the cell-surface, after that it solubilizes these lipids with apolipoproteins and binds apolipoproteins, through which it activates signaling processes. ABCA1 is expressed in the pancreatic beta cells, and its expression was found to be less in leukocytes from patients with T2DM [136]. In the sequence of ABCA1 gene on chromosome 9q31.1, several polymorphisms have been reported in association with altered lipid profile and diseases like atherosclerosis, CVD, CAD, Alzheimer disease as well as T2DM in different ethnic groups [137-141]. The p.230R $>C$ variant is associated with T2DM, particularly of early onset, in the Mexican-Mestizo population [139]. However, a Danish research group could not detect association between the presence of p.1800N $>\mathrm{H}$ ABCA1 variants and increased risk of T2DM. Besides, in a study, which involved young Greek nurses, only the rs2230808: p.1587R $>\mathrm{K}$ $(\mathrm{MAF}(\mathrm{E}): 0.839 ; \operatorname{MAF}(\mathrm{A}): 0.711)$ variant was shown to decrease LDL-cholesterol levels among three ABCA1 alterations (rs2230806: p.219R $>\mathrm{K}$ MAF(E): 0.792; $\mathrm{MAF}(\mathrm{A}): 0.576 ; \mathrm{rs} 2230808$ : $\mathrm{p} .1587 \mathrm{R}>\mathrm{K}$ and rs4149313: p.883I>M MAF(E): 0.133; $\operatorname{MAF(A):~0.576)~[142].~}$

\section{Peroxisome proliferator-activated receptors (PPARs)}

The members of this protein family are nuclear transcription factors which form heterodimers with retinoic acid X receptor and hereby can activate or repress transcription of various genes involved in lipid metabolism [143]. PPARs bind to specific DNA elements (peroxisome-proliferator response elements, PPRE) on target genes through which they modulate DNA transcription [144]. PPARs consist of a DNA-binding domain stabilized by zinc cations bound to cysteine residues, a ligand-binding domain regulated by ligand binding and dimerization. One of the three common subtypes of PPARs is PPAR $\gamma$, which is expressed in adipose tissue and gut. The PPAR $\gamma$ controls glucose and lipid metabolism, free fatty acid transport, cell proliferation, adipocyte differentiation and mitochondrial biogenesis [145]. Additionally, PPAR $\gamma$ has been implicated in the pathology of various diseases. The gene, which encodes PPAR $\gamma$ is located on chromosome 3p25. Polymorphisms in PPAR $\gamma$ gene may contribute to the risk of hypertriglyceridemia independently and/or in an interactive manner [146]. The rs1801282: Pro12Ala variant (MAF(E): 0.076; MAF(A): 0.056) is the most widely studied, common alteration of the PPAR $\gamma$ gene, which is highly prevalent in Caucasians. The 12Ala allele has been associated with a reduction of T2DM risk. This result was declared in 1998 and since then it has been confirmed in several studies [147]. Besides, other alterations in the PPARG gene, g.161C $>\mathrm{T}$ was shown to reduce the risk of severe atherogenesis by modulation of triglycerides and apoB in Chinese patients with CAD and T2DM [148]

\section{Conclusion}

Beside the above mentioned variants, there are other possible genetic markers that can contribute to the development of T2DM. Certain polymorphisms, such as those found in the MLX interacting protein-like (MLXIPL), angiopoietin-like 3 (ANGPLT3), human tribbles-1 (TRIB1), FADS gene cluster, have been found to confer risk for several diseases like dyslipidemia, hypertriglyceridemia, $\mathrm{CHD}$, CVD. The role of these genes and genetic variants has not yet been investigated in association with T2DM. It is well known that the disorders above are associated with many metabolic abnormalities, in this particular case in lipid metabolism, which suggest that they might have also shared susceptibility genes and alleles. In numerous GWA studies, variants in the GALNT, MLXIPL, TRIB1 and FADS genes have been found to have triglyceride-rising effect, which can serve as a link between increased triglyceride-related phenotypes. To discover these relations, further studies are needed on genetic variants in these genes.

\section{Acknowledgements}

This work was supported by grants from the Hungarian Scientific Research Foundation, OTKA K 103983 and by TÁMOP SROP-4.2.2/B-10/1-2010-0029 Supporting Scientific Training of Talented Youth at the University of Pécs. 
Citation: Sümegi K, Melegh B, Maasz A, Kisfali P, Bene J, et al. (2013) Triglyceride Level Affecting Shared Susceptibility Genetic Variants in Type 2 Diabetes Mellitus. J Diabetes Metab S13: 007. doi:10.4172/2155-6156.S13-007

\section{References}

1. Shaw JE, Sicree RA, Zimmet PZ (2010) Global estimates of the prevalence of diabetes for 2010 and 2030. Diabetes Res Clin Pract 87: 4-14.

2. Wild S, Roglic G, Green A, Sicree R, King H (2004) Global prevalence of diabetes: estimates for the year 2000 and projections for 2030. Diabetes Care 27: 1047-1053.

3. Stumvoll M, Goldstein BJ, van Haeften TW (2005) Type 2 diabetes: principles of pathogenesis and therapy. Lancet 365: 1333-1346.

4. Prokopenko I, McCarthy MI, Lindgren CM (2008) Type 2 diabetes: new genes, new understanding. Trends Genet 24: 613-621.

5. Zimmet P, Alberti KG, Shaw J (2001) Global and societal implications of the diabetes epidemic. Nature 414: 782-787

6. Unwin N, Gan D, Whiting D (2010) The IDF Diabetes Atlas: providing evidence, raising awareness and promoting action. Diabetes Res Clin Pract 87: 2-3.

7. Knowler WC, Pettitt DJ, Saad MF, Bennett PH (1990) Diabetes mellitus in the Pima Indians: incidence, risk factors and pathogenesis. Diabetes Metab Rev 6: 1-27.

8. Zimmet P, Dowse G, Finch C, Serjeantson S, King H (1990) The epidemiology and natural history of NIDDM--lessons from the South Pacific. Diabetes Metab Rev 6: 91-124.

9. NEEL JV (1962) Diabetes mellitus: a "thrifty" genotype rendered detrimental by "progress"? Am J Hum Genet 14: 353-362.

10. Cowie CC, Rust KF, Ford ES, Eberhardt MS, Byrd-Holt DD, et al. (2009) Ful accounting of diabetes and pre-diabetes in the U.S. population in 1988-1994 and 2005-2006. Diabetes Care 32: 287-294.

11. Brancati FL, Kao WH, Folsom AR, Watson RL, Szklo M (2000) Incident type 2 diabetes mellitus in African American and white adults: the Atherosclerosis Risk in Communities Study. JAMA 283: 2253-2259.

12. Chan JC, Malik V, Jia W, Kadowaki T, Yajnik CS, et al. (2009) Diabetes in Asia: epidemiology, risk factors, and pathophysiology. JAMA 301: 2129-2140.

13. Koopman RJ, Mainous AG 3rd, Diaz VA, Geesey ME (2005) Changes in age at diagnosis of type 2 diabetes mellitus in the United States, 1988 to 2000. Ann Fam Med 3: 60-63.

14. Rosenbloom AL, Joe JR, Young RS, Winter WE (1999) Emerging epidemic of type 2 diabetes in youth. Diabetes Care 22: 345-354.

15. DeFronzo RA (1988) Lilly lecture 1987. The triumvirate: beta-cell, muscle, liver. A collusion responsible for NIDDM. Diabetes 37: 667-687.

16. Kahn SE (2001) Clinical review 135: The importance of beta-cell failure in the development and progression of type 2 diabetes. J Clin Endocrinol Metab 86: 4047-4058.

17. Brownlee M (2001) Biochemistry and molecular cell biology of diabetic complications. Nature 414: 813-820.

18. Maechler $P$, Wollheim CB (2001) Mitochondrial function in normal and diabetic beta-cells. Nature 414: 807-812.

19. Pickup JC, Crook MA (1998) Is type II diabetes mellitus a disease of the innate immune system? Diabetologia 41: 1241-1248.

20. GOODMAN JI, WASSERMAN S, MARCUS LJ, FRANKEL L (1950) A study of atherosclerosis in a group of diabetic patients. Am J Med Sci 220: 30-45.

21. WILENS SL (1953) The relation of diabetes to atherosclerosis. N Y State J Med 53: $2451-2452$

22. Lavy S, Melamed E, Cahane E, Carmon A (1973) Hypertension and diabetes as risk factors in stroke patients. Stroke 4: 751-759.

23. [No authors listed] (1966) Blindness and diabetes. N Engl J Med 274: 1384.

24. Lennhoff M, Herrera J (1968) Acute renal failure in diabetic acidosis. Lance 1: 758

25. Leibson CL, Rocca WA, Hanson VA, Cha R, Kokmen E, et al. (1997) Risk of dementia among persons with diabetes mellitus: a population-based cohort study. Am J Epidemiol 145: 301-308.

26. Huang QY, Cheng MR, Ji SL (2006) Linkage and association studies of the susceptibility genes for type 2 diabetes. Yi Chuan Xue Bao 33: 573-589.
27. Froguel P, Velho G (1999) Molecular Genetics of Maturity-onset Diabetes of the Young. Trends Endocrinol Metab 10: 142-146.

28. van den Ouweland JM, Lemkes HH, Trembath RC, Ross R, Velho G, et al (1994) Maternally inherited diabetes and deafness is a distinct subtype of diabetes and associates with a single point mutation in the mitochondrial tRNA(Leu(UUR)) gene. Diabetes 43: 746-751.

29. Fischer-Rosinsky A, Fisher E, Kovacs $P$, Blüher M, Möhlig M, et al. (2008) Lack of association between the tagging SNP A+930-->G of SOCS3 and type 2 diabetes mellitus: meta-analysis of four independent study populations. PLoS One 3: e3852.

30. Yamakawa-Kobayashi K, Natsume M, Aoki S, Nakano S, Inamori T, et al. (2012) The combined effect of the T2DM susceptibility genes is an importan risk factor for T2DM in non-obese Japanese: a population based case-control study. BMC Med Genet 13: 11

31. Diabetes Genetics Initiative of Broad Institute of Harvard and MIT, Lund University, and Novartis Institutes of BioMedical Research, Saxena R, Voigh BF, et al. (2007) Genome-wide association analysis identifies loci for type 2 diabetes and triglyceride levels. Science 316: 1331-1336.

32. Scott LJ, Mohlke KL, Bonnycastle LL, Willer CJ, Li Y, et al. (2007) A genomewide association study of type 2 diabetes in Finns detects multiple susceptibility variants. Science 316: 1341-1345.

33. Sladek R, Rocheleau G, Rung J, Dina C, Shen L, et al. (2007) A genome-wide association study identifies novel risk loci for type 2 diabetes. Nature 445: 881 885

34. Zeggini E, Weedon MN, Lindgren CM, Frayling TM, Elliott KS, et al. (2007) Replication of genome-wide association signals in UK samples reveals risk loci for type 2 diabetes. Science 316: 1336-1341.

35. Voight BF, Scott LJ, Steinthorsdottir V, Morris AP, Dina C, et al. (2010) Twelve type 2 diabetes susceptibility loci identified through large-scale association analysis. Nat Genet 42: 579-589.

36. Ahlqvist E, Ahluwalia TS, Groop L (2011) Genetics of type 2 diabetes. Clin Chem 57: 241-254

37. Rong R, Hanson RL, Ortiz D, Wiedrich C, Kobes S, et al. (2009) Association analysis of variation in/near FTO, CDKAL1, SLC30A8, HHEX, EXT2, IGF2BP2, LOC387761, and CDKN2B with type 2 diabetes and related quantitative traits in Pima Indians. Diabetes 58: 478-488.

38. Dallongeville J, Lussier-Cacan S, Davignon J (1992) Modulation of plasma triglyceride levels by apoE phenotype: a meta-analysis. J Lipid Res 33: 447454

39. Pitas RE, Innerarity TL, Mahley RW (1980) Cell surface receptor binding of phospholipid . protein complexes containing different ratios of receptor-active and -inactive E apoprotein. J Biol Chem 255: 5454-5460.

40. Ye S, Dunleavey L, Bannister W, Day LB, Tapper W et al (2003) Independent effects of the $-219 \mathrm{G}>\mathrm{T}$ and epsilon 2/ epsilon 3/ epsilon 4 polymorphisms in the apolipoprotein $\mathrm{E}$ gene on coronary artery disease: the Southampton Atherosclerosis Study. Eur J Hum Genet 11: 437-443.

41. Utermann G, Hees M, Steinmetz A (1977) Polymorphism of apolipoprotein E and occurrence of dysbetalipoproteinaemia in man. Nature 269: 604-607.

42. Granér M, Kahri J, Varpula M, Salonen RM, Nyyssönen K, et al. (2008) Apolipoprotein $\mathrm{E}$ polymorphism is associated with both carotid and coronary atherosclerosis in patients with coronary artery disease. Nutr Metab Cardiovasc Dis 18: $271-277$

43. Song Y, Stampfer MJ, Liu S (2004) Meta-analysis: apolipoprotein E genotypes and risk for coronary heart disease. Ann Intern Med 141: 137-147.

44. Chaudhary R, Likidlilid A, Peerapatdit T, Tresukosol D, Srisuma S, et al. (2012 Apolipoprotein $\mathrm{E}$ gene polymorphism: effects on plasma lipids and risk of type 2 diabetes and coronary artery disease. Cardiovasc Diabetol 11: 36.

45. Powell DS, Maksoud H, Chargé SB, Moffitt JH, Desai M, et al. (2003) Apolipoprotein E genotype, islet amyloid deposition and severity of Type 2 diabetes. Diabetes Res Clin Pract 60: 105-110.

46. Kim JH, Lee EJ, Kwon OH (1997) Apolipoprotein E genotyping and phenotyping in type II diabetes mellitus patients with hypertriglyceridemia. Clin Biochem 30 47-52.

47. Kamboh MI, Aston CE, Hamman RF (1995) The relationship of APOE polymorphism and cholesterol levels in normoglycemic and diabetic subjects 
in a biethnic population from the San Luis Valley, Colorado. Atherosclerosis 112: $145-159$.

48. Oh JY, Barrett-Connor E; Rancho Bernardo Study Group (2001) Apolipoprotein E polymorphism and lipid levels differ by gender and family history of diabetes: the Rancho Bernardo Study. Clin Genet 60: 132-137.

49. Dixit M, Bhattacharya S, Mittal B (2005) Association of CETP Taql and APOE polymorphisms with type II diabetes mellitus in North Indians: a case control study. BMC Endocr Disord 5: 7

50. Jong MC, Hofker MH, Havekes LM (1999) Role of ApoCs in lipoprotein metabolism: functional differences between ApoC1, ApoC2, and ApoC3. Arterioscler Thromb Vasc Biol 19: 472-484.

51. Miller M, Rhyne J, Chen H, Beach V, Ericson R, et al. (2007) APOC3 promoter polymorphisms C-482T and T-455C are associated with the metabolic syndrome. Arch Med Res 38: 444-451.

52. Olivieri O, Bassi A, Stranieri C, Trabetti E, Martinelli N, et al. (2003) Apolipoprotein C-III, metabolic syndrome, and risk of coronary artery disease. J Lipid Res 44: 2374-2381.

53. Olivieri O, Stranieri C, Bassi A, Zaia B, Girelli D, et al. (2002) ApoC-III gene polymorphisms and risk of coronary artery disease. J Lipid Res 43: 1450-1457.

54. Pollin TI, Damcott CM, Shen H, Ott SH, Shelton J, et al. (2008) A null mutation in human APOC3 confers a favorable plasma lipid profile and apparent cardioprotection. Science 322: 1702-1705.

55. Dorfmeister B, Cooper JA, Stephens JW, Ireland H, Hurel SJ, et al. (2007) The effect of APOA5 and APOC3 variants on lipid parameters in European Whites, Indian Asians and Afro-Caribbeans with type 2 diabetes. Biochim Biophys Acta 1772: $355-363$

56. Merkel M, Heeren J (2005) Give me A5 for lipoprotein hydrolysis! J Clin Invest 115: 2694-2696.

57. Weinberg RB, Cook VR, Beckstead JA, Martin DD, Gallagher JW, et al. (2003) Structure and interfacial properties of human apolipoprotein A-V. J Biol Chem 278: 34438-34444

58. Schaap FG, Rensen PC, Voshol PJ, Vrins C, van der Vliet HN, et al. (2004) ApoAV reduces plasma triglycerides by inhibiting very low density lipoproteintriglyceride (VLDL-TG) production and stimulating lipoprotein lipase-mediated VLDL-TG hydrolysis. J Biol Chem 279: 27941-27947.

59. Groenendijk M, Cantor RM, de Bruin TW, Dallinga-Thie GM (2001) The apoAlCIII-AIV gene cluster. Atherosclerosis 157: 1-11.

60. Hadarits F, Kisfali P, Mohas M, Maasz A, Sumegi K, et al. (2011) Stepwise positive association between APOA5 minor allele frequencies and increasing plasma triglyceride quartiles in random patients with hypertriglyceridemia of unclarified origin. Pathol Oncol Res 17: 39-44.

61. Havasi V, Szolnoki Z, Talián G, Bene J, Komlósi K, et al. (2006) Apolipoprotein A5 gene promoter region $\mathrm{T}-1131 \mathrm{C}$ polymorphism associates with elevated circulating triglyceride levels and confers susceptibility for development of ischemic stroke. J Mol Neurosci 29: 177-183.

62. Horvatovich K, Bokor S, Baráth A, Maász A, Kisfali P, et al. (2011) Haplotype analysis of the apolipoprotein A5 gene in obese pediatric patients. Int J Pediat Obes 6: e318-325.

63. Hubacek JA (2005) Apolipoprotein A5 and triglyceridemia. Focus on the effects of the common variants. Clin Chem Lab Med 43: 897-902.

64. Kisfali P, Mohás M, Maász A, Polgár N, Hadarits F, et al. (2010) Haplotype analysis of the apolipoprotein A5 gene in patients with the metabolic syndrome. Nutr Metab Cardiovasc Dis 20: $505-511$.

65. Kisfali P, Mohás M, Maasz A, Hadarits F, Markó L, et al. (2008) Apolipoprotein A5 IVS3+476A allelic variant associates with increased trigliceride levels and confers risk for development of metabolic syndrome in Hungarians. Circ J 72: $40-43$

66. Maasz A, Kisfali P, Jaromi L, Horvatovich K, Szolnoki Z, et al. (2008) Apolipoprotein A5 gene IVS3+G476A allelic variant confers susceptibility for development of ischemic stroke. Circ J 72: 1065-1070.

67. Maász A, Kisfali P, Szolnoki Z, Hadarits F, Melegh B (2008) Apolipoprotein A5 gene C56G variant confers risk for the development of large-vessel associated ischemic stroke. J Neurol 255: 649-654.

68. Maász A, Kisfali P, Horvatovich K, Mohás M, Markó L, et al. (2007)
Apolipoprotein A5 T-1131C variant confers risk for metabolic syndrome. Pathol Oncol Res 13: 243-247.

69. Mattei J, Demissie S, Tucker KL, Ordovas JM (2009) Apolipoprotein A5 polymorphisms interact with total dietary fat intake in association with markers of metabolic syndrome in Puerto Rican older adults. J Nutr 139: 2301-2308.

70. Pennacchio LA, Olivier M, Hubacek JA, Krauss RM, Rubin EM, et al. (2002) Two independent apolipoprotein A5 haplotypes influence human plasma triglyceride levels. Hum Mol Genet 11: 3031-3038.

71. Talmud PJ (2007) Rare APOA5 mutations--clinical consequences, metabolic and functional effects: an ENID review. Atherosclerosis 194: 287-292.

72. Bhaskar S, Ganesan M, Chandak GR, Mani R, Idris MM, et al. (2011) Association of PON1 and APOA5 gene polymorphisms in a cohort of Indian patients having coronary artery disease with and without type 2 diabetes. Genet Test Mol Biomarkers 15: 507-512.

73. Li X, Xu Y, Ding Y, Qin C, Dai Z, et al. (2008) Polymorphism of apolipoprotein A5 is a risk factor for cerebral infarction in type 2 diabetes. J Huazhong Univ Sci Technolog Med Sci 28: 653-656.

74. Braun JE, Severson DL (1992) Regulation of the synthesis, processing and translocation of lipoprotein lipase. Biochem J 287 : 337-347.

75. Merkel M, Eckel RH, Goldberg IJ (2002) Lipoprotein lipase: genetics, lipid uptake, and regulation. J Lipid Res 43: 1997-2006.

76. Mattu RK, Needham EW, Morgan R, Rees A, Hackshaw AK, et al. (1994) DNA variants at the LPL gene locus associate with angiographically defined severity of atherosclerosis and serum lipoprotein levels in a Welsh population. Arterioscler Thromb 14: 1090-1097.

77. Peacock RE, Hamsten A, Johansson J, Nilsson-Ehle P, Humphries SE (1994) Associations of genotypes at the apolipoprotein Al-CIII-AIV, apolipoprotein B and lipoprotein lipase gene loci with coronary atherosclerosis and high density lipoprotein subclasses. Clin Genet 46: 273-282.

78. Kastelein JJ, Ordovas JM, Wittekoek ME, Pimstone SN, Wilson WF, et al (1999) Two common mutations (D9N, N291S) in lipoprotein lipase: a cumulative analysis of their influence on plasma lipids and lipoproteins in men and women. Clin Genet 56: 297-305.

79. Goodarzi MO, Guo X, Taylor KD, Quiñones MJ, Saad MF, et al. (2004) Lipoprotein lipase is a gene for insulin resistance in Mexican Americans. Diabetes 53: 214-220.

80. Hu Y, Liu W, Huang R, Zhang X (2006) A systematic review and meta-analysis of the relationship between lipoprotein lipase Asn291Ser variant and diseases. J Lipid Res 47: 1908-1914.

81. Gagné SE, Larson MG, Pimstone SN, Schaefer EJ, Kastelein JJ, et al. (1999) A common truncation variant of lipoprotein lipase (Ser447X) confers protection against coronary heart disease: the Framingham Offspring Study. Clin Genet 55: $450-454$

82. Muñoz-Barrios S, Guzmán-Guzmán IP, Muñoz-Valle JF, Salgado-Bernabé AB, Salgado-Goytia L, et al. (2012) Association of the Hindlll and S447X polymorphisms in LPL gene with hypertension and type 2 diabetes in Mexican families. Dis Markers 33: 313-320.

83. Hall S, Chu G, Miller G, Cruickshank K, Cooper JA, et al. (1997) A common mutation in the lipoprotein lipase gene promoter, $-93 T / G$, is associated with lower plasma triglyceride levels and increased promoter activity in vitro. Arterioscler Thromb Vasc Biol 17: 1969-1976.

84. Talmud PJ, Hall S, Holleran S, Ramakrishnan R, Ginsberg HN, et al. (1998) LPL promoter $-93 \mathrm{~T} / \mathrm{G}$ transition influences fasting and postprandial plasma triglycerides response in African-Americans and Hispanics. J Lipid Res 39 1189-1196.

85. Hu Y, Ren Y, Luo RZ, Mao X, Li X et al. (2007) Novel mutations of the lipoprotein lipase gene associated with hypertriglyceridemia in members of type 2 diabetic pedigrees. J Lipid Res 48: 1681-1688.

86. Cho YS, Go MJ, Han HR, Cha SH, Kim HT, et al. (2008) Association of lipoprotein lipase (LPL) single nucleotide polymorphisms with type 2 diabetes mellitus. Exp Mol Med 40: 523-532.

87. Zechner R, Kienesberger PC, Haemmerle G, Zimmermann R, Lass A (2009) Adipose triglyceride lipase and the lipolytic catabolism of cellular fat stores. $J$ Lipid Res 50: 3-21.

88. Zimmermann R, Strauss JG, Haemmerle G, Schoiswohl G, Birner-Gruenberger 
$\mathrm{R}$, et al. (2004) Fat mobilization in adipose tissue is promoted by adipose triglyceride lipase. Science 306: 1383-1386.

89. Nanni L, Quagliarini F, Megiorni F, Montali A, Minicocci I, et al. (2010) Genetic variants in adipose triglyceride lipase influence lipid levels in familial combined hyperlipidemia. Atherosclerosis 213: 206-211.

90. Yao-Borengasser A, Varma V, Coker RH, Ranganathan G, Phanavanh B, et al. (2011) Adipose triglyceride lipase expression in human adipose tissue and muscle. Role in insulin resistance and response to training and pioglitazone. Metabolism 60: 1012-1020.

91. Xu S, Yang G, Yang M, Li S, Liu H, et al. (2011) Elevated adipose triglyceride lipase in newly diagnosed type 2 diabetes mellitus with hypertension. Am J Med Sci 342: 452-455.

92. Schoenborn V, Heid IM, Vollmert C, Lingenhel A, Adams TD, et al. (2006) The ATGL gene is associated with free fatty acids, triglycerides, and type 2 diabetes. Diabetes 55: 1270-1275.

93. Tzotzas T, Desrumaux C, Lagrost L (2009) Plasma phospholipid transfer protein (PLTP): review of an emerging cardiometabolic risk factor. Obes Rev 10: 403-411.

94. Jarvik GP, Rajagopalan R, Rosenthal EA, Wolfbauer G, McKinstry L, et al (2010) Genetic and nongenetic sources of variation in phospholipid transfer protein activity. J Lipid Res 51: 983-990.

95. Song GJ, Han GH, Chae JJ, Namkoong Y, Lee HK, et al. (1997) The effects of the cholesterol ester transfer protein gene and environmental factors on the plasma high density lipoprotein cholesterol levels in the Korean population. Mo Cells 7: 615-619.

96. Freeman DJ, Griffin BA, Holmes AP, Lindsay GM, Gaffney D, et al. (1994) Regulation of plasma HDL cholesterol and subfraction distribution by genetic and environmental factors. Associations between the Taq B RFLP in the CETP gene and smoking and obesity. Arterioscler Thromb 14: 336-344.

97. Meguro S, Takei I, Murata M, Hirose H, Takei N, et al. (2001) Cholesteryl ester transfer protein polymorphism associated with macroangiopathy in Japanese patients with type 2 diabetes. Atherosclerosis 156: 151-156.

98. Tai ES, Ordovas JM, Corella D, Deurenberg-Yap M, Chan E, et al. (2003) The TaqIB and $-629 \mathrm{C}>\mathrm{A}$ polymorphisms at the cholesteryl ester transfer protein locus: associations with lipid levels in a multiethnic population. The 1998 Singapore National Health Survey. Clin Genet 63: 19-30.

99. Dallinga-Thie GM, van Tol A, Dullaart RP; Diabetes Atorvastatin lipid intervention (DALI) study group (2009) Plasma pre beta-HDL formation is decreased by atorvastatin treatment in type 2 diabetes mellitus: Role of phospholipid transfer protein. Biochim Biophys Acta 1791: 714-718.

100. Attia N, Nakbi A, Smaoui M, Chaaba R, Moulin P, et al. (2007) Increased phospholipid transfer protein activity associated with the impaired cellula cholesterol efflux in type 2 diabetic subjects with coronary artery disease. Tohoku J Exp Med 213: 129-137.

101.Barhanin J, Lesage F, Guillemare E, Fink M, Lazdunski M, et al. (1996) K(V) LQT1 and IsK (minK) proteins associate to form the I(Ks) cardiac potassium current. Nature 384: 78-80.

102. Yasuda K, Miyake K, Horikawa Y, Hara K, Osawa H, et al. (2008) Variants in KCNQ1 are associated with susceptibility to type 2 diabetes mellitus. Nat Genet 40: 1092-1097.

103. Unoki H, Takahashi A, Kawaguchi T, Hara K, Horikoshi M, et al. (2008) SNPs in KCNQ1 are associated with susceptibility to type 2 diabetes in East Asian and European populations. Nat Genet 40: 1098-1102.

104. Liu Y, Zhou DZ, Zhang D, Chen Z, Zhao T, et al. (2009) Variants in KCNQ1 are associated with susceptibility to type 2 diabetes in the population of mainland China. Diabetologia 52: 1315-1321.

105. Tan JT, Nurbaya S, Gardner D, Ye S, Tai ES, et al. (2009) Genetic variation in KCNQ1 associates with fasting glucose and beta-cell function: a study of 3,734 subjects comprising three ethnicities living in Singapore. Diabetes 58 $1445-1449$

106. Hu C, Wang C, Zhang R, Ma X, Wang J, et al. (2009) Variations in KCNQ1 are associated with type 2 diabetes and beta cell function in a Chinese population. Diabetologia 52: 1322-1325.

107.Sun Q, Song K, Shen X, Cai Y (2012) The association between KCNQ1 gene polymorphism and type 2 diabetes risk: a meta-analysis. PLoS One 7: e48578.
108. Chen Z, Yin Q, Ma G, Qian Q (2010) KCNQ1 gene polymorphisms are associated with lipid parameters in a Chinese Han population. Cardiovasc Diabetol 9: 35.

109. Hayward BE, Fantes JA, Warner JP, Intody S, Leek JP, et al. (1996) Colocalization of the ketohexokinase and glucokinase regulator genes to a 500 $\mathrm{kb}$ region of chromosome 2p23. Mamm Genome 7: 454-458.

110. Farrelly D, Brown KS, Tieman A, Ren J, Lira SA, et al. (1999) Mice mutant for glucokinase regulatory protein exhibit decreased liver glucokinase: a sequestration mechanism in metabolic regulation. Proc Natl Acad Sci U S A 96: $14511-14516$

111. Grimsby J, Coffey JW, Dvorozniak MT, Magram J, Li G, et al. (2000) Characterization of glucokinase regulatory protein-deficient mice. J Biol Chem 275: 7826-7831.

112. Warner JP, Leek JP, Intody S, Markham AF, Bonthron DT (1995) Human glucokinase regulatory protein (GCKR): CDNA and genomic cloning, complete primary structure, and chromosomal localization. Mamm Genome 6: 532-536.

113. Veiga-da-Cunha M, Delplanque J, Gillain A, Bonthron DT, Boutin P, et al. (2003) Mutations in the glucokinase regulatory protein gene in $2 p 23$ in obese French caucasians. Diabetologia 46: 704-711.

114. Vaxillaire M, Vionnet N, Vigouroux C, Sun F, Espinosa R 3rd, et al. (1994) Search for a third susceptibility gene for maturity-onset diabetes of the young. Studies with eleven candidate genes. Diabetes 43: 389-395.

115. Vaxillaire M, Cavalcanti-Proenca C, Dechaume A, Tichet J, Marre M, et al (2008) The common P446L polymorphism in GCKR inversely modulates fasting glucose and triglyceride levels and reduces type 2 diabetes risk in the DESIR prospective general French population. Diabetes 57: 2253-2257.

116. Orho-Melander M, Melander O, Guiducci C, Perez-Martinez P, Corella D, et al. (2008) Common missense variant in the glucokinase regulatory protein gene is associated with increased plasma triglyceride and C-reactive protein but lower fasting glucose concentrations. Diabetes 57: 3112-3121.

117. Køster B, Fenger M, Poulsen P, Vaag A, Bentzen J (2005) Nove polymorphisms in the GCKR gene and their influence on glucose and insulin levels in a Danish twin population. Diabet Med 22: 1677-1682.

118. Sparsø T, Andersen G, Nielsen T, Burgdorf KS, Gjesing AP, et al. (2008) The GCKR rs780094 polymorphism is associated with elevated fasting serum triacylglycerol, reduced fasting and OGTT-related insulinaemia, and reduced risk of type 2 diabetes. Diabetologia 51: 70-75.

119. Tam CH, Ma RC, So WY, Wang Y, Lam VK, et al. (2009) Interaction effect of genetic polymorphisms in glucokinase (GCK) and glucokinase regulatory protein (GCKR) on metabolic traits in healthy Chinese adults and adolescents. Diabetes 58: 765-769.

120. Willer CJ, Sanna S, Jackson AU, Scuteri A, Bonnycastle LL, et al. (2008) Newly identified loci that influence lipid concentrations and risk of coronary artery disease. Nat Genet 40: 161-169.

121. Shen H, Pollin TI, Damcott CM, McLenithan JC, Mitchell BD, et al. (2009) Glucokinase regulatory protein gene polymorphism affects postprandial lipemic response in a dietary intervention study. Hum Genet 126: 567-574.

122. Weissglas-Volkov D, Aguilar-Salinas CA, Sinsheimer JS, Riba L, HuertasVazquez A, et al. (2010) Investigation of variants identified in caucasian genome-wide association studies for plasma high-density lipoprotein cholesterol and triglycerides levels in Mexican dyslipidemic study samples. Circ Cardiovasc Genet 3: 31-38.

123. Onuma H, Tabara Y, Kawamoto R, Shimizu I, Kawamura R, et al. (2010) The GCKR rs780094 polymorphism is associated with susceptibility of type 2 diabetes, reduced fasting plasma glucose levels, increased triglycerides levels and lower HOMA-IR in Japanese population. J Hum Genet 55: 600-604.

124. Mohás $M$, Kisfali $P$, Járomi L, Maász A, Fehér E, et al. (2010) GCKR gene functional variants in type 2 diabetes and metabolic syndrome: do the rare variants associate with increased carotid intima-media thickness? Cardiovasc Diabetol 9: 79.

125. Járomi L, Csöngei V, Polgár N, Szolnoki Z, Maász A, et al. (2010) Functional variants of glucokinase regulatory protein and apolipoprotein A5 genes in ischemic stroke. J Mol Neurosci 41: 121-128.

126. Stark K, Reinhard W, Grassl M, Erdmann J, Schunkert H, et al. (2009) Common polymorphisms influencing serum uric acid levels contribute to susceptibility to gout, but not to coronary artery disease. PLoS One 4: e7729. 
Citation: Sümegi K, Melegh B, Maasz A, Kisfali P, Bene J, et al. (2013) Triglyceride Level Affecting Shared Susceptibility Genetic Variants in Type 2 Diabetes Mellitus. J Diabetes Metab S13: 007. doi:10.4172/2155-6156.S13-007

Page 8 of 8

127.Dupuis J, Langenberg C, Prokopenko I, Saxena R, Soranzo N, et al. (2010) New genetic loci implicated in fasting glucose homeostasis and their impact on type 2 diabetes risk. Nat Genet 42: 105-116.

128. Qi Q, Wu Y, Li H, Loos RJ, Hu FB, et al. (2009) Association of GCKR rs780094, alone or in combination with GCK rs1799884, with type 2 diabetes and related traits in a Han Chinese population. Diabetologia 52: 834-843.

129. Furuhashi M, Ura N, Nakata T, Shimamoto K (2003) Insulin sensitivity and lipid metabolism in human CD36 deficiency. Diabetes Care 26: 471-474.

130. Febbraio M, Hajjar DP, Silverstein RL (2001) CD36: a class B scavenger receptor involved in angiogenesis, atherosclerosis, inflammation, and lipid metabolism. J Clin Invest 108: 785-791.

131. Ma X, Bacci S, Mlynarski W, Gottardo L, Soccio T, et al. (2004) A common haplotype at the CD36 locus is associated with high free fatty acid levels and increased cardiovascular risk in Caucasians. Hum Mol Genet 13: 2197-2205.

132. Love-Gregory L, Sherva R, Sun L, Wasson J, Schappe T, et al. (2008) Variants in the CD36 gene associate with the metabolic syndrome and high-density lipoprotein cholesterol. Hum Mol Genet 17: 1695-1704.

133. Leprêtre F, Vasseur F, Vaxillaire M, Scherer PE, Ali S, et al. (2004) A CD36 nonsense mutation associated with insulin resistance and familial type 2 diabetes. Hum Mutat 24: 104.

134. Gautam S, Banerjee M (2011) The macrophage Ox-LDL receptor, CD36 and its association with type II diabetes mellitus. Mol Genet Metab 102: 389-398.

135. Corpeleijn E, van der Kallen CJ, Kruijshoop M, Magagnin MG, de Bruin TW, et al. (2006) Direct association of a promoter polymorphism in the CD36/FAT fatty acid transporter gene with Type 2 diabetes mellitus and insulin resistance. Diabet Med 23: 907-911.

136. Patel DC, Albrecht C, Pavitt D, Paul V, Pourreyron C, et al. (2011) Type 2 diabetes is associated with reduced ATP-binding cassette transporter A1 gene expression, protein and function. PLoS One 6: e22142.

137. Tang C, Oram JF (2009) The cell cholesterol exporter ABCA1 as a protector from cardiovascular disease and diabetes. Biochim Biophys Acta 1791: 563572

138. Villarreal-Molina MT, Flores-Dorantes MT, Arellano-Campos O, VillalobosComparan M, Rodríguez-Cruz M, et al. (2008) Association of the ATP-binding cassette transporter A1 R230C variant with early-onset type 2 diabetes in a Mexican population. Diabetes 57: 509-513.

139. Villarreal-Molina T, Posadas-Romero C, Romero-Hidalgo S, AntúnezArgüelles E, Bautista-Grande A, et al. (2012) The ABCA1 gene R230C variant is associated with decreased risk of premature coronary artery disease: the genetics of atherosclerotic disease (GEA) study. PLoS One 7: e49285.

140. Jiang M, Lv L, Wang H, Yang X, Ji H, et al. (2012) Meta-analysis on association between the ATP-binding cassette transporter A1 gene (ABCA1) and Alzheimer's disease. Gene 510: 147-153

141. Li YY, Zhang H, Qin XY, Lu XZ, Yang B, et al. (2012) ATP-binding cassette transporter A1 R219K polymorphism and coronary artery disease in Chinese population: a meta-analysis of 5,388 participants. Mol Biol Rep 39: 1103111039.

142. Kolovou V, Marvaki A, Karakosta A, Vasilopoulos G, Kalogiani A et al. (2012) Association of gender, ABCA1 gene polymorphisms and lipid profile in Greek young nurses. Lipids Health Dis 11: 62.

143. Burrage PS, Schmucker AC, Ren Y, Sporn MB, Brinckerhoff CE (2008) Retinoid $X$ receptor and peroxisome proliferator-activated receptor-gamma agonists cooperate to inhibit matrix metalloproteinase gene expression. Arthritis Res Ther 10: R139.

144. Schachtrup C, Emmler T, Bleck B, Sandqvist A, Spener F (2004) Functional analysis of peroxisome-proliferator-responsive element motifs in genes of fatty acid-binding proteins. Biochem J 382: 239-245.

145. Michalik L, Wahli W (2008) PPARs Mediate Lipid Signaling in Inflammation and Cancer. PPAR Res 2008: 134059.

146. Gu SJ, Liu MM, Guo ZR, Wu M, Chen Q, et al. (2013) Gene-gene interactions

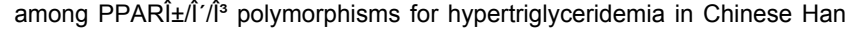
population. Gene 515: 272-276.

147. Gouda HN, Sagoo GS, Harding AH, Yates J, Sandhu MS, et al. (2010) The association between the peroxisome proliferator-activated receptor-gamma2 (PPARG2) Pro12Ala gene variant and type 2 diabetes mellitus: a HuGE review and meta-analysis. Am J Epidemiol 171: 645-655.

148. Wan J, Xiong S, Chao S, Xiao J, Ma Y, et al. (2010) PPARgamma gene C161T substitution alters lipid profile in Chinese patients with coronary artery disease and type 2 diabetes mellitus. Cardiovasc Diabetol 9: 13.
This article was originally published in a special issue, Type 2 Diabetes Mellitus- Disease, Diagnosis \& Treatment handled by Editors. Dr. Judit Bene, University of Pécs, Hungary; Eun Seok Kang, Yonsei University College of Medicine, Korea 